\title{
THE ROLE OF NORTH CAUCASUS IN THE SECURITY OF RUSSIAN FEDERATION
}

\author{
Przemysław Jan Sieradzan \\ Institute of Political Science, University of Gdansk
}

\begin{abstract}
The article is focusing on the dilemmas of post-imperial statehood in the context of Russian Federation security, with the particular emphasis on the fundamental alternative: to maintain the poly-ethnic (quasi-imperial) model of state, or to build a nation state. The Author defines the concept of "empire" from the point of view of three determinants: the concentric structure based on centerperiphery dichotomy, orientation towards the external mission and imperial idea. From this point of view, Russia is an imperial state (contrary to Tsarist Empire and USSR), and is not a typical nation state. The author tries to demonstrate that the abandonment of federal, multinational state model would be tantamount to the loss of strategically important North Caucasus, which would deprive it of a regional power status. The study contains a multi-faceted exploration of the North Caucasus (which is a highly turbulent region) as a key territory for the global dimension of geo-strategy. The Author analyzes potential threats to North Caucasian security and actions taken by Moscow in order to prevent them. He pays attention to the growing popularity of slogans about the necessity of separation of Caucasus and Russia. In his opinion, Caspian-Black Sea Region would become a zone of global destabilization, posing a threat to the world peace.
\end{abstract}

The Russian State (understood very widely, as a geopolitical centre of power, which over centuries took various different hypostases - Kievan Rus, Moscow Rus, Russian Empire, Union of Soviet Socialist Republics, and Russian Federation) is commonly mythologized in the discourse of the West. Aberrant stereotypes, prejudices, and mystified ideas are so deeply ingrained in minds of journalists, analysts and researchers, that too often prevent the rational (sine ira et studio) reflection. It should be noted that mythologized perception of Russia, its leaders and international policy has some intrinsic contradictions. That is why the myth of Russian Federation can be invincible and pathetic, dangerous and powerless, repulsive and fascinating in the same time ${ }^{1}$. This idiosyncratic dialectic (very similar to unio oppositorum - the unity of contradictions, known from the works by Medieval philosopher Nicholas of Cusa) has its source in a common perception of the irrational nature of Russian civilization, culture, and statehood. As an evidence of the thesis, according to which the interpretation of socio-political processes in the largest country of the world is a challenge is an impossible task for human (more precisely: Western) mind, people bring, as a rule without understanding and out of context, quotes from the classics of Russian poetry: Fyodor Tyutchev ("Who would grasp Russia with the mind?")

1 See: P.J. Sieradzan, Postrzeganie Rosji przez pryzmat nostalgii po utraconym imperium, [in:] S. Bieleń [ed.] Wizerunki międzynarodowe Rosji, Warszawa 2011. 
and Alexandr Blok („Russia is Sphinx”). The presentation of an Eastern power as an inscrutable and mysterious civilizational space usually has one goal - the release of the investigator from the cognitive effort.

Caucasus is at least equally mythologized. Here one can also see a kind of dialectics of contradictory images, which had its source in stereotypes and mystification. There is a "black legend" of the Caucasus as a battlefield where for centuries cruel and barbaric tribes endlessly wage wars, and a „white legend” of sky-reaching, unreachable mountains, compelling by its harsh beauty, inhabited by proud and freedom-loving nations.

The researcher who wants to conceptualize the role of Caucasus (in this case, its northern part) for the security of Russian Federation is facing a difficult challenge. This research problem is double-mythologized. Its accurate exploration requires a large dose of criticism and reception of culturally conditioned, mystified ideas. The author of this study is deeply convinced that both Russia and the Caucasus are not cultural spaces based on irrationality. Undoubtedly, they are autonomous in an axiological sense, and their logic of historical process differs from West European.

It is impossible to understand the role of North Caucasus for contemporary Russia without conceptualizing the model of contemporary Russian statehood. The main question is whether Russia is a national state or an empire.

An essence of imperial statehood is its heterogeneity - an empire is a transnational and supranational structure. It includes a large number of different political, administrative, ethnic, and cultural entities.

The various entities creating the empire enjoy a certain degree of autonomy (both in the administrative and cultural sense), but recognize the sovereignty of the imperial Center ${ }^{2}$. One can distinguish two levels of the imperial structure (central and local). In fact, the structure of the distribution of power in the empire can be much more complex. While in some cases the range of autonomy of some subjects can be quite broad, the Center is the only instance authorized to make decisions on key issues, particularly war and peace, security, and foreign policy. The imperial structure is based on a "center-periphery" contradiction that should not necessarily have a spatial dimension.

Stanisław Bieleń proposes another important feature of the imperial state model: focus on the outer mission (libido dominandi), which does not necessarily mean the territorial expansion by military means, but rather "projecting oneself" (its statehood model and culture) into new territories ${ }^{3}$. Weakening empires can move their focus

\footnotetext{
2 See. A. Dugin, Obščestvovedenie, Moskva 2007, op. cit., p. 166-167.

3 S. Bieleń, Postimperializm - neoimperializm - transimperializm: próba oceny rosyjskiej polityki zagranicznej, [in:] S. Bieleń, A. Skrzypek [ed.] Rosja. Refleksje o transformacji, Warszawa 2010, p. 237.
} 
of interest into the domestic issues, thereby forgoing the expansion. This moment, however, is usually the beginning of disintegration of the empire.

In the foundation of every empire lies a specific idea (imperial idea) of a political, ideological or metaphysical nature. This idea unites all the parts of an empire within one union ${ }^{4}$, underlying whole multi-level imperial structure. It provides legitimation to the authority of the Center over the peripheries. Delegitimization of the imperial idea in the eyes of the denizens of the empire has always centrifugal tendencies, leading to the dissolution of the imperial structure. Using force by the Centre can postpone this process, but not prevent it ${ }^{5}$.

Union of Soviet Socialist Republics had all the three features described above. The structure of power in the USSR was multi-leveled and concentric. Undoubtedly it had a sovereign Center (Moscow). The first circle was Russian Socialist Federal Soviet Republic. Not only capital-Center was located on its territory, but also most of the objects important from the point of view of economy, defense, and science. The other 14 socialist republics were the second circle. While the constitutional right to secession remained a fiction, the local authorities (for example in Central Asia) often had a very large extent of autonomy in their internal politics.

The independence of the republican power elites were tolerated as long as those elites remained loyal towards the Centre and did not questioned its sovereign power. The third imperial circle included the satellite states of the USSR, which were members of Warsaw Treaty and COMECON. The level of their autonomy was much higher, than that of the Soviet republics - they had independent authorities and their own internal and foreign policy. However, those states were subject to the „limited sovereignty" rule, according to which USSR had a right for military intervention in case of any threat to the coherence and interests of socialist bloc. The fourth circle consisted of the socialist republics of the Third World and non-socialist states which adopted a pro-Soviet policy out of pragmatic reasons 6 .

The peripheral states had a large extent of political sovereignty, while they remained dependent from the Center in economic, ideological, cultural, and often also military aspect. In the same time they had the smallest influence on the policy of the empire as a whole 7 .

The dissolution of a Soviet empire begun with the fourth circle - as early as in the beginning of perestroika the Soviet authorities limited their economic and military support for the Third World countries. On the verge of 80's and 90's of the 20th century the Center lost its third circle - the satellite states in the Eastern Europe. The

4 See: A. Dugin, Osnovy geopolitiki, Moskva 2000, p. 904.

5 See: P.J. Sieradzan, Postrzeganie Rosji przez pryzmat nostalgii, op. cit.

6 The latter subgroup may include Finland, which was economically dependent on the USSR, but also part of the Arab states, especially in the 60's of the twentieth century (Egypt, Syria).

7 See. W. Marciniak, Rozgrabione imperium, Kraków 2004, A. Dugin, Osnovy... 
consequence of proclamation of sovereignty and independence by Soviet republics was the final dissolution of USSR in the 1991 (and thus the dissolution of the second circle). The disintegration of the first circle (Russian Federation) was very probable in the $90 \mathrm{~s}$ of $20^{\text {th }}$ century, but was prevented by the president Vladimir Putin.

The national emblem of Soviet Union (hammer and sickle on the background of the Earthly Globe) is the symbol of the external expansion focus. From the moment of its creation in 1922, USSR continually extended not only its territory, but also the range of its political and cultural influence. Even in the final period of Leonid Brezhnev's reign the Soviet empire expanded its geopolitical influence in Latin America, the Horn of Africa, and Indochina. Resignation from the expansion (perishing of libido dominandi) with the start of perestroika was the beginning of the end of the USSR.

The Marxism-leninism was an imperial idea in the USSR. It had their followers not only within the empire itself, but also beyond its borders - both in the Third World and in dissident circles of capitalist world. As late as in the 70's, the socialist model of development was highly popular. The socialist idea erosion, which manifesting itself in ideological dogmatism, was certainly one of the main causes of the collapse of the USSR ${ }^{8}$.

The dissolution of the Union of Soviet Socialist Republics was tantamount to the defeat of socialist camp in the Cold War and the end of bipolar model in international relations. Contrary to Zbigniew Brzezinski's prediction, a socialist superpower was not replaced by a geopolitical black hole ${ }^{9}$, but by fifteen centers of power, differently defining their own national interests and pursuing different goals. Russian Federation is undoubtedly the strongest of them, because it kept the vast majority of the Soviet geopolitical potential: territory, population, armed force, intellectual basis, technology, special forces, and last but not least, strategic nuclear force. Without the slightest exaggeration, Russian Federation can be called not only legal, but also geopolitical heir of the Soviet Union.

Russian Federation is not an empire, nor a regular national state. It is not a superpower, but it undoubtedly belongs to the global elite of world powers. The power of the Soviet Union was so vast that the Russian Federation which inherited the largest part of the "bankruptcy estate" of the former superpower is still able to exert significant influence in the international reality ${ }^{10}$. The legacy of the fallen superpower itself, combined with the unique geopolitical location and the huge amount of natural resources makes Russia an international power.

8 S. Kara-Murza, Sovetskaâ civilizaciâ, Moskva 2009, p. 548-549.

9 See: Z. Brzezinski, The Grand Chessboard: American Primacy and its Geostrategic Imperatives, New York 1998, p. 46-63.

10 See: J. Potulski, Współczesne kierunki rosyjskiej myśli geopolitycznej. Między nauką, ideologicznym dyskursem a praktyką, Gdańsk 2010, p. 19-21. 
From the point of view of administrative structure, Russian Federation is much more similar to empire than to the national state. The artificial concept equivalent to West European political nation, is not used in spoken language. Russkie - Russians in the ethnic sense - are about $80 \%$ of Russian citizens, but they are not mentioned in any legal act fundamental from the point of view of constitutional order. In Constitution of Russian Federation we read about "multi-national people of Russia" (mnogonacijonalnyj narod Rossii), which suggests imperial or quasi-imperial character of the state ${ }^{11}$.

On August 6 $6^{\text {th }}, 1990$ Boris Yeltsin, then the chairman of Supreme Council of Russian Socialist Federal Soviet Republic, pronounced his famous address in Ufa (the capital of Bashkiria). He said: "take the amount of power that you are able to swallow"12. These words were understood as a call for dismantling of the empire. The local elites were very quick to react. The authorities of many subjects of Russia declared their sovereignty ${ }^{13}$. Boris Yeltsin as a President of Russian Federation took some steps to prevent the „sovereignty parade” process that was started by himself. He has led to the signing of new federal agreement on March 31 st, 1992. It was signed by all the federal subjects apart from Chechnya and Tatarstan.

If the "parade of sovereignty" was continued, Russian Federation would quickly transform itself from post-empire into national state. The harmonious balance between local and central government level is necessary for the proper functioning of such an imperial state. The series of secession on the area of Russian Federation would undoubtedly interfere with this balance, reducing the power of Center. This process was stopped by Vladimir Putin, who won the second Chechen war and started administrative reform of 2000, thanks to which Russia was divided into seven federal areas ${ }^{14}$, and introduced a rule of appointing the heads of federal subjects by the Russian president in $2004^{15}$.

It is doubtful whether contemporary Russian Federation is oriented to the external mission. During Boris Yeltsin tenure, the regular and irregular Russian units participated in conflicts in the post-Soviet area (South Ossetia, Abkhazia, Nagorny Karabakh, Transdnistria, Tajikistan), but the goal of those interventions was rather the maintenance of status quo than expansion. In the same time, Russian

${ }^{11}$ Zob. Konstituciâ Rossijskoj Federacii.

12 Berite stol'ko suvereniteta, skol'ko smožete proglotit', „Izvestiâ” August 8th, 1990.

13 The declarations of sovereignty were announced by following ASSR (Autonomous Soviet Socialist Republics): Komi, Tatarstan, Udmurtia, Yakutsk-Sakh, Chuvashia, Kalmykiya, Buriatia, Bashkiria, and Chukotka, Adyghea, Yamalo-Nenets and Upper Altay Autonomous Districts.

14 See: Ukaz Prezidenta RF ot 13 maâ 2000 g. „O polnomočnom predstavitele Priezidenta Rossijskoj Fedieracii w Federal'nom Okruge, No. 849.

15 See: J. Ćwiek-Karpowicz, Reforma władzy państwowej w okresie prezydentury Władimira Putina, [in:] S. Bieleń, A. Skrzypek, op. cit., p. 61-75. 
troops withdrew from Eastern Europe. Most of foreign bases in the other regions were closed. Russia resigned from its political, economic, and military influence all over the world. Thus we might rather talk about imperial implosion rather than expansionism. During Vladimir Putin's reign mostly "defensive" actions were taken. They were aimed at the preserving of status quo (preventing the disintegration of Russia), but also "offensive" actions, like support for pro-Russian political powers on post-Soviet area, striving for supremacy, and efficient intelligence actions.

It is arguable in what extent contemporary Russia has the first two of the mentioned features of the empire. It has the multi-level structure of power and is a supranational state. Separatist movements, mostly in the North Caucasus region, still pose a threat to its territorial integrity. There is no doubt, however, that contemporary Russian Federation does not fill the third determinant of imperial statehood. The contemporary Russia did not worked out any idea that could become a foundation of imperial rebirth.

The dominating Marxism-Leninism was replaced by an ideological vacuum. Russian Federation is currently not able to present its potential allies a new and attractive doctrine, socio-economic or constitutional model.

Russian Federation - a post-imperial state - is currently at the crossroad. Its identity is in status nascendi. Russia stands against the necessity of choice between building its national statehood and preserving the remains of its imperial (or quasiimperial) model. It is difficult to tell which way the Russia will choose.

Preservation of quasi-imperial model of statehood will be tantamount to keeping the status quo. Russia as poly-ethnic federal state will keep the status of a regional power and potential to regain the world power status. What is more, Moscow will be able to initiate the integration projects on post-Soviet area (like Organization of Collective Defense Treaty, Eurasian Economic Commonwealth or Eurasian Union). The multinational Russian Federation which could overcome the temptation of turning to nationalist ideology, could become a most important factor of stabilization in a very turbulent region of former USSR. The bloc of states concentrated around Russia can become a partner for another regional security or mutual defense organization.

The choice of national state model could make integration with western structures possible. Undoubtedly it would foster the gain of international investments. A lack of necessity of up keeping the mighty army would become a strong stimulus for economic development. Russian national state, breaking with centuries-lasting tradition of imperial model, would surely become an economic partner for the West. This project could gain a wide popularity among the part of Russian society sympathetic to the ideas of Occidentalism (zapadnichestvo), but also nationalists, who claim that a multinational model of statehood is disadvantageous for ethnic Russians, who support culturally alien national republics. The choice of a national 
state (rejection of the poly-ethnicity principle) would have a number of consequences posing a threat not only to Russia, but also to whole region.

The project of the ethnic Russian national state (usually called "the Republic of Rus" as opposed to Latinized form of "Russia" coined in the time of Peter the Great, the creator of Empire) is popular in nationalist, national-democratic, and, to some extent, liberal. It is based on the pro-Western civilizational choice and rejection of control of Moscow over the ethnically alien territories. Thus the rejection of poly-ethnic, post-imperial model of statehood would inevitably be a cause of territorial loses. There is no doubt that it would end with a series of secessions of national republics. Their national elites would not accept the national minority status in Russian ethnic states. Countering the national liberation (in some cases irredentist) movements would be in stark contrast to the very idea of a nation state. The authorities of a new state (Rus) would have to accept the process of secession of non-Slavic inhabited territories.

The first to secede would probably be the citizens of North Caucasus, an extremely unstable and heterogeneous region with a very complex ethnic structure, comprising of over a hundred ethnic and sub ethnic groups, a myriad of languages and dialects, and the whole spectrum of local traditions.

The Caucasus region for centuries had a strategic importance for Russian center of power, striving to get an access to Southern Seas (Indian Ocean above all). This goal was not fulfilled during Tzar's reign, nor it was during the communist rule. An access to the Southern Seas was a stake of Russian-English Great Game in Caucasus ${ }^{16}$. The Afghan War ${ }^{17}$ was the last attempt of Moscow's geopolitical offensive to the South. It ended with a crouching defeat of Soviet Army.

The loss of Caucasus would make critical the geopolitical location of Russia, that even now is extremely unfavorable. With a little exaggeration one can say that after the collapse of Soviet Union in 1991 the western border of the country went back to the position of the Moscow Tsardom. Russian access to the World Ocean is very limited. The land border is very long and mostly artificial, which makes it very difficult to defend. This is how analysts of a private-owned intelligence bureau STRATFOR describe the geopolitical situation of Russian Federation as very severe in the context of NATO expansion and lose of Belarus, Ukraine, and Central Asia, not to mention the lack of geographical barriers on most of the borders ${ }^{18}$.

The southern border of Russian Empire and USSR was based on barriers almost impossible to cross by numerous armies of invaders: barren deserts, mountain ranges, and great water reservoirs. The southern border of the empire ranged from Okhotsk

${ }^{16}$ See: M. Leontev, Bolšaâ igra. Britanskaâ imperiâ protiv Rossii i SSSR, Sankt-Peterburg 2008.

17 Afghanistan do not have an access to the see, but it crucial geopolitical location in South-West Asia makes the control over the Afhgan territory a key factor of domination in the region.

18 STRATFOR, Geopolitics of Russia: Permanent struggle, www.stratfor.com (March 27 th 2012 ). 
Sea to the Black Sea and was secured from the foreign invasion on its every section. The endless Siberian forests, swamps and wilderness, Mongol deserts, Tien-Shan Mountains (northern extension of Himalaya), Caspian Sea, Caucasus Mountains and Black Sea defended the southern outskirts of the empire.

After the loss of Central Asia by Moscow, the southern border of Russia became much more difficult to defend. The Mountains of the Great Caucasus between Black and Caspian Sea are the only solid natural barrier on this territory. Russia lost Transcaucasia, while North Caucasus is under its control, while being extremely unstable. The lost of even one republic of Ciscaucasia would be a stunning blow for the security of Russian Federation. That would create a potential beachhead for invasion to the north of Great Caucasus. Such invasion would be extremely difficult to fight off. The defense of southern border of Russia against the military aggression would become an impossible task.

The importance of North Caucasus for the national security of Russia is extremely high. The loss of control over the region would make the Eurasian power almost defenseless against any aggression. What is more, in case of Caucasus secession, Russia loses its access to the Black Sea, what makes its already limited access to the World Ocean very difficult. Not only the withdrawal from the Caucasus would finally disperse dreams of a part of Russian political elite about the restoration of global power status, but would be tantamount to losing the status of a regional power.

Maintaining the North Caucasus is crucial for federal, multinational Russia. This is why Moscow strategy in the region is based on permanent support for the stability in Ciscausacia by means of providing help to the local elites loyal towards Moscow, preventing ethnic conflicts and countering any centrifugal tendencies ${ }^{19}$.

The secession of North Caucasus would probably mean that the whole region would immerse in a bloody war. Moscow-forsaken region would become a battlefield of local warlords struggling for power and influence. The pan-Caucasian identity (concerning a potential pan-ethnic Caucasian nation) that could potentially underlay a regional federation was only an idea popular among emigration circles after October Revolution, but did not achieve any wider popularity. The members of particular nations are deeply divided in ethnic, cultural, language, and religious dimension (most of Caucasians follow the Sunni version of Islam - the most notable exception to this rule are mostly orthodox Ossetians. However, it should be noted that Islam in Caucasus is permeated with traditional metaphysics and rituals having their roots in pre-Muslim spirituality ${ }^{20}$.

\footnotetext{
19 See: S. Bieleń, Tożsamość międzynarodowa Federacji Rosyjskiej, Warszawa 2006.

20 See: Islam na obszarze postradzieckim. Materiał analityczny Ośrodka Studiów Wschodnich, Warszawa 2003.
} 
Most probably the particular national republics would be the ones to secede. It would be naive to think that their leaders (representatives of ethnic elites) would have accepted the actual borders between the subjects of North Caucasian subjects of federation, which include Dagestan, Ingushetia, Chechnya, North Osetia, Kabardino-Balkaria, Karachay-Cherkessia and Adygea (which is an enclave in the territory of Krasnodar Kray inhabited mostly by Russians). Most of the national republics could not autocratically transform into independent states, because most of them are absolutely artificial. It applies mostly to the twonational republic model, which is a part of the Soviet legacy. It was implemented to overcome ethnic particularisms. The intention of this kind of entity was that the two title nationalities should balance each other's influence, putting an end to the mutual hatred and allowing for harmonious coexistence. The existence of two-national territorial entities in Caucasus ${ }^{21}$ served the role of creation of supra ethnic entity giving primacy of loyalty to the Soviet state over the national and territorial particularities 22 .

It is hard to imagine that multinational territorial formation, the existence of which was included in broader content of Soviet statehood, could become the cornerstone of the nation state. The wars in Kabardino-Balkaria and Karachay-Cherkessia would start immediately. Adyghe (Kabardians and Circassians) and Turks (Karachays and Balkars) will start to fight against each other. On should also remember, that poly-ethnic Dagestan is also an artificial structure. This mountainous republic on the western coast of the Caspian Sea is inhabited by seven main ethnic groups. None of them will voluntarily agree for their marginalization.

While without the active participation of Moscow (the federal centre) it is difficult to imagine a consensus over a quota system, allowing all the ethnic groups to participate in the share of power, with high probability we can assume that Dagestan would immerse in a bloody civil war.

The eternal border conflict between Ossetians and Ingushes would probably start once again. The Chechen civil war between Muslim fundamentalists (Wahhabites), secular nationalists, and the supporters of traditional model of social organization based on the clan structure.

The loss of North Caucasus by Moscow would not only create a bloody and brutal civil war in the region between Black Sea and Caspian Sea between different ethnic and interest groups (bellum omni contra omnes). The territory would enter a period of anarchy and chaos. It would become a sanctuary for international terrorists and a potential center for world Muslim fundamentalism. It would amount to

21 These were the Karachay-Cherkess Autonomous Oblast, Chechen-Ingush Autonomous Soviet Socialist Republic and Kabardino-Balkar Autonomous Soviet Socialist Republic.

22 See: T. Bodio, P. Sieradzan, The Struggle over the form of the Political System of the Karachay-Circassian Republic among the Ruling Elites, "Polish Political Science Yearbook", 2012 (in print). 
transformation of Caucasus into the zone of not only local, but also global destabilization (which is a result of the crucial location of Caucasus at the interface between the macro regions playing a key role for World geostrategy - post-Soviet area, the Middle East, and South Asia).

It should be noted that the whole project of incorporation of North Caucasus into Russian civilizational space. Attempts of Russification of the region in Tsarist time and promoting supra ethnic "Soviet patriotism" left their imprint on the local customs, but did not change the identity and collective consciousness of the population $^{23}$.

However, the former power of Moscow center enabled the central management of Caucasus region by Russian elites and loyal representatives of local ethnic elites. In the 90's the situation has radically changed. Moscow lost the ability to exercise effective control over the region in the way it used to.

Given the complete collapse of the Soviet model of culture, a renaissance of political institutions of traditional society occurred. The same applied to religion, ethnic consciousness and clan ties. The ethnic, clan, and religious identity proved to be stronger that a bond with Moscow. The Russian populace fled from the region, fearing repressions and ethnic cleansing. In the region of Caucasus separatist counter elites emerged. They adhered to the ideas of nationalism or religious fundamentalism, ready to issue a challenge to the official elites, often of Soviet origin.

The Chechen (Ichkerian) separatism was particularly significant in this context. Russian elites were afraid that local leaders of Dagestan, Ingushetia, KabardinoBalkaria, and Karachay-Cherkessia may follow an example of Dzhohar Dudaev, the leader of anti-Russian uprising.

The demographic processes in Caucasus, which are extremely disadvantageous for Russia (Russians are only 10 per cent of the population in the Caucasus and their number permanently decreases), and the rise of popularity of separatism forced Moscow to base their control over the region on the local ethnic elite (more precisely: the part of local ethnic elite which declared its loyalty to Moscow). The local ethnic elites had been given the possibility to remain the broad independence in internal policy of national republics.

In tzarist Russia and USSR occurred a process of modernization of Caucasus. This process was violently aborted at the time of dissolution of Soviet Union. Later, it was reversed. Parallel with Moscow's resignation from attempts to integrate the region within the Russian civilizational field, in North Caucasus re-tribalization and re-tribalization processes took place, what is very obvious in the eastern part of the region. Tribal, clan, and religious institution began to

23 See: E. Matuszek, Narody pótnocnego Kaukazu. Historia-kultura-konflikty 1985-1991, Toruń 2007, p. 11-44. 
displace official state-imposed law (what is more they often filled the vacuum created as a result of lack of effective mechanisms of state authority). That is why some researchers begun to call Caucasus "an alien civilization enclave within the borders of Russia" 24 .

The evolution of Russia's approach to North Caucasus can be noticed on the example of Chechnya can be noticed on the example of Chechnya, which after the signing of the Khasav-Yurta Accords from August 31 st $1996^{25}$, which became a de facto independent state. The emergence and rise of popularity of Chechen separatist movement led by Dzhohar Dudaev was a result of deep authority crisis of Kremlin and erroneous national policy of Moscow. For many years Checheno-Ingushetia was ruled by Russians or local politicians not popular in the region ${ }^{26}$.

After a humiliating defeat of the First Chechen War of 1994-1996, Russian Federation faced a threat of losing Caucasus. After assuming the presidency in 2000, Vladimir Putin was forced to change the policy in the region, trying to fix the errors and mistakes of his predecessors (in the 90s Moscow alternatively left Chechnya alone or used military force). New president decided to form an alliance with part of local power elites. It is significant that the figure of Ahmad Kadyrov became a key factor of Russian plan of stabilizing the situation on north-eastern part of Caucasus. This politician, former separatist activist and mufti of Chechen Republic of Ichkeria of 1995-2000 had a vast authority among the Chechen populace, including the veterans of the war of 1994-1996.

The choice of popular Ahmad Kadyrov, who combined traditionalist outlook with loyalty towards Moscow, enabled the stabilization of region by Moscow, but after the assassination of president from May 9th, 2004 the region faced the risk of destabilization once more. Alu Alkhanov became the temporary president of turbulent region, who was replaced in 2007 by Ahmad Kadyrov's son Ramzan (immediately after reaching 30 years of age demanded by constitution). Ramzan Kadyrov was widely perceived as a bearer of his father's legacy ${ }^{27}$.

One should remark that the change of Kremlin policy towards the local elites in the Caucasus occurred in parallel with the centralization of administrative system in Russia (ukreplene vertikali vlasti) ${ }^{28}$ - resignation from direct elections of the subjects of federation. Presidential nominees usually originated from the local ruling elites

${ }^{24}$ See: M. Falkowski, M. Marszewski, Kaukaskie terytoria plemienne - cywilizacyjnie obca enklawa w granicach Rosji, Warszawa 2010.

25 See: A. Stanley, Yeltsin Signs Peace Treaty With Chechnya, "New York Times", May 13 ${ }^{\text {th }}, 1997$.

26 See: E. Matuszek, Narody Pótnocnego Kaukazu..., op. cit., s. 160-161.

27 See: V. Korovin, Nakanune imperii. Prikladnaă geopolitika i setevye vojny, Moskva 2008, p. 194-205 .

28 Zob. Ǔ. Latynina, O vertikali vlasti, „Ežednevnyj Žurnal”, March 2nd, 2009. 
while there were some exceptions to this rule (a notable exception was lawyer and scholar Boris Ebzeev, the president of Karachay-Cherkessia form 2008-2011, who inefficiently tried to eliminate the ethnic and clan factor from regional policy ${ }^{29}$.

The creation of Northcaucasian Federal Area, headed by the economist and manager Aleksandr Khloponin could be a breakthrough in Moscow policy towards the region.

For now, however, it is difficult to talk about the reversal of disadvantageous civilizational trends in Caucasus. The power of Wahhabi underground is widely overrated, nevertheless the region immerses in chaos, posing a threat to Russian statehood and safety in the region ${ }^{30}$.

The meaning of North Caucasus for the Russian geopolitical strategy is so immense that decisive actions aimed to regulate the unstable situation seem unavoidable. The escalation of even one of the "frozen" conflict in Caucasus during the Olympic Games of 2014 creates a risk of international shame, while the secession of one of the national republics would lead to territorial disintegration of the state. Meanwhile, the xenophobic slogans gain popularity in Russia. Every November $4^{\text {th }}$ so-called "Russian Marches" are organized by nationalist and anti-Caucasian organizations. Nationalist activists rise the slogan "Stop feeding the Caucasus", trying to force Moscow to leave the turbulent region on its own. The perception of Caucasians as citizens of the second category is not limited to overtly xenophobic and extremist circles. Russian nationalists openly call for separation of North Caucasus from Russia by "sanitary cordon". Foundation of "ethnically clean" state of East Slavs (which is supported by some nationalists) would be tantamount to voluntary rejection of regional power status by Russia.

Russian Federation, while weakened and struggling against many internal problems, remains the most influential power of the Caucasus. If the elites in the Kremlin not work out a consistent and efficient strategy for the region, Moscow will unavoidably lose its strategic initiative, giving it away to another participants in the Great Game for Caucasus, Washington in the first place. Losing influence in the Caucasus would be the road of political marginalization of Russian Federation, which would become a peripheral state in geopolitical structure of the world order. In the first place, it would be tantamount to the destabilization of a crucial region of global security, which would pose a threat to the world peace.

${ }^{29}$ See: Kreml' nazval prichiny otstavki glavy Karačaevo-Čerkesii, http://lenta.ru/news/2011/02/26/cause/ (April, 11th 2012 r.).

30 See: P.J. Sieradzan, Ku nowej <<Wielkiej Grze >> - rywalizacja mocarstw światowych o przywództwo geopolityczne w regionie Kaukazu, [in:] T. Bodio, Przywództwo, elity i ośrodki siły na Kaukazie, Warszawa 2012 (in preparation). 


\section{LITERATURA:}

1. J. AdAmowski, A. Skrzypek (red.), Federacja Rosyjska 1991-2001, Warszawa 2002.

2. J.N. Afanasjew, Groźna Rosja, Warszawa 2005.

3. A. Andrusiewicz, Mit Rosji, Rzeszów 1994.

4. A.S. BARSENKow, A.I. Wdowin, Istorija Rossii 1917-2004, Moskwa 2006.

5. Z. Brzeziński, Wielka szachownica. Główne cele polityki amerykańskiej, Warszawa 1999.

6. A. Dugin, Absoliutnaja Rodina, Moskwa 1998.

7. A. Dugin, Fiłosofija politiki, Moskwa 2004.

8. A. Dugin, Jewrazijskij Put', Moskwa 2002.

9. A. Dugin [red.], Jewrazijskij Wzgliad, Moskwa 2002.

10. A. Dugin, Osnowy gieopolitiki, Moskwa 2000.

11. Goriacza mołodioż Rossii. Lidiery. Organizacii i dwiżenija. Taktika ulicznych bitw. Kontakty, Moskwa 2006.

12. J. Gancewski, J. Sobczak (red.), Europa a Rosja. Przeszłość, teraźniejszość, przyszłość, Elbląg 2005.

13. S. Huntington, Zderzenie cywilizacji i nowy kształt ładu światowego, Warszawa 1998.

14. I. Iwanow, Rossija w sowriemennom mirie. Otwiety na wyzowy XXI wieka, Moskwa 2004.

15. A. Janow, Poslie Jelcyna: „wiejmarskaja Rossija”, Moskwa 1995.

16. M. KaŁAsZnikow, Słomannyj miecz impierii, Moskwa 1999.

17. M. KaŁasznikow, S. Kuguszew, Trietij projekt, Moskwa 2005.

18. S. KarA-Murza, Marks protiw russkoj riewoliucii, Moskwa 2008.

19. S. Kara-Murza, Anti-sowietskij projekt, Moskwa 2009.

20. S. Kara-Murza, Diemontaż naroda, Moskwa 2007.

21. S. Kara-Murza, Matrica Rossija, Moskwa 2007.

22. S. Kara-Murza, Riewoliucii na eksport, Moskwa 2005.

23. S. Kara-Murza, Oppozicija kak tieniewaja włast', Moskwa 2006.

24. S. Kara-Murza, Oranżewaja mina, Moskwa 2008.

25. S. Kara-Murza, Sowietskaja ciwilizacija. Ot naczała do wielikoj pobiedy, Moskwa 2001.

26. S. Kara-Murza, Sowietskaja ciwilizacija. Ot wielikoj pobiedy do naszych dniej, Moskwa 2001.

27. J.E. Korguniuk, C.E. ZasŁAwskiJ, Rossijskaja mnogopartijnost’, Moskwa 1996.

28. W. Korowin, Nakanunie imperii. Prikładnaja gieopolitika i sietiewyje wojny, Moskwa 2008.

29. S. Kurginian, Postpierestrojka, Moskwa 1990.

30. S. Kurginian, Siedmoj scenarij, Moskwa 1992. 
31. M. LARUelle, Russian Eurasianism. Ideology of the Empire, przeł. Mischa Grabowitsch, Washington D.C., 2008.

32. A. De LAZARI, Czy Moskwa będzie trzecim Rzymem? Studia o nacjonalizmie rosyjskim, Katowice 1996.

33. A. DE LAZARI, Idee w Rosji. Leksykon rosyjsko-polsko-angielski, Łódź 2001.

34. W. MarciniaK, Rozgrabione imperium. Upadek Zwiazku Sowieckiego i powstanie Federacji Rosyjskiej, Kraków 2001.

35. W. Marciniak, Przestrzeń jako kategoria dyskursu politycznego w Rosji współczesnej, Warszawa 2002.

36. E. Matuszek, Narody północnego Kaukazu. Historia-kultura-konflikty 1985-1991, Toruń 2007.

37. M. McFaul, Russia's Unfinished Revolution. Political change from Gorbachev to Putin, Ithaca-London 2001.

38. F. Memches, Studzy i wrogowie imperium. Rosyjskie rozmowy o końcu historii, Kraków 2009.

39. Mir Rossii - Jewrazija. Antołogija, Moskwa 1995.

40. Mentalność rosyjska. Słownik encyklopedyczny, Katowice 1995.

41. R. Miedwiediew, Kapitalizm w Rossii?, Moskwa 1998.

42. L. Moczulski, Geopolityka: potega w czasie i przestrzeni, Warszawa 1999.

43. Sz. Munczajew, W. Ustinow, Istorija sowietskogo gosudarstwa, Moskwa 2003.

44. N. Narocznickaja, Rossija i russkije w mirowoj istorii, Moskwa 2005.

45. N. Narocznickaja, Russkij mir, Moskwa 2007.

46. Naucznyj almanach. Kultury i ciwilizacii. Rossija i wostok. Gieopolitika i ciwilizacionnyje otnoszenija, Moskwa 1994.

47. R. PARAdowski, Eurazjatyckie Imperium Rosji. Studium Idei, Toruń 2001.

48. J. Potulski, Współczesne kierunki rosyjskiej myśli geopolitycznej. Między nauką, ideologicznym dyskursem a praktyką, Gdańsk 2010.

49. Rossija mieżdu Jewropoj i Aziej. Jewrazijskij sobłazn, Moskwa 1993.

50. Politiczeskije partii Rossii: istorija i sowriemiennost', Moskwa 2000.

51. A. Prochanow, Operacja Heksogen, przeł. E. Zych, Warszawa 2005.

52. A. Prochanow, Piataja impierija, Moskwa 2007.

53. S. Bieleń, A. Skrzypek [red.], Rosja. Refleksje o transformacji, Warszawa 2010.

54. S. Bieleń [red.], Wizerunki międzynarodowe Rosji, Warszawa 2011.

55. S. Bieleń, Tożsamość międzynarodowa Federacji Rosyjskiej, Warszawa 2006.

56. P.J. Sieradzan, Aksamitni terroryści. Narodowy bolszewizm w Federacji Rosyjskiej, Warszawa 2008.

57. A. Soвсzaк, Przed upadkiem, Warszawa 1992.

58. W. Sogrin, Politiczeskaja istorija sowriemennoj Rossiji. 1985-2001: od Gorbaczowa do Putina, Moskwa 2001. 


\section{Znaczenie Kaukazu Północnego dla bezpieczeństwa Federacji Rosyjskiej}

Streszczenie. Artykuł poświęcony jest dylematom państwowości postimperialnej w kontekście bezpieczeństwa Federacji Rosyjskiej, ze szczególnym uwzględnieniem fundamentalnej alternatywy: utrzymania modelu państwowości polietnicznej (quasi-imperialnej) lub budowania państwa narodowego. Autor definiuje pojęcie „imperium” z punktu widzenia trzech wyznaczników: koncentrycznej struktury opartej na dychotomii centrum i peryferii, orientacji na misję zewnętrzną oraz idei imperialnej. Z tego punktu widzenia Federacja Rosyjska nie jest państwem imperialnym (w odróżnieniu od Cesarstwa Rosyjskiego i ZSRR), nie jest jednak typowym państwem narodowym. Autor usiłuje wykazać, że rezygnacja $\mathrm{z}$ federacyjnego, wielonarodowego modelu państwowości byłaby równoznaczna z utratą przez Rosję strategicznie ważnego Kaukazu Północnego, co pozbawiłoby ją statusu mocarstwa regionalnego. Studium zawiera wielostronną analizę Kaukazu Północnego (który jest regionem niezwykle turbulentnym) jako terytorium kluczowego dla globalnego wymiaru geostrategii. Autor analizuje potencjalne zagrożenia dla północnokaukaskiego bezpieczeństwa oraz działania podejmowane przez Moskwę w celu zapobieżenia im. Zwraca również uwagę na rosnącą popularność haseł o konieczności oddzielenia Kaukazu od Rosji. W jego przekonaniu region kaspijsko-czarnomorski stałby się wówczas strefą globalnej destabilizacji, zagrażając pokojowi na świecie. 